\title{
Evolutions of Nonlinear Acoustics and Microstructure Induced by Plastic Strain in a Low Carbon Steel
}

by

\author{
Toshihiro Ohtani*, Yutaka Ishï**, Masayuki Kamaya***, \\ and Takayuki SAKAKIBARA****
}

\begin{abstract}
Electromagnetic acoustic resonance (EMAR) is a contactless resonant method with an electromagnetic acoustic transducer (EMAT). This method enables not only to measure exact ultrasonic attenuation of measured sample but also to eliminate nonlinear acoustic effect between the sample and transducer. In this study, the EMAR was applied to investigate the relationships between nonlinear acoustic characterizations; resonant frequency shift, three-wave mixing and birefringence acoustoelasticity and microstructural changes induced by tensile plastic strain in a low-carbon steel, JIS-S25C. Furthermore, we developed a single bulk-shear-wave EMAT which was composed of three-layer elongated coils and a pair of permanent magnets to measure in three-wave mixing. The EMAT transmits and receives shear wave propagating in thickness direction of a plate specimen. Three nonlinear acoustic parameters and ultrasonic attenuation increased with increase in tensile plastic strain. This phenomenon is interpreted as resulting from microstructure changes, especially, dislocation density and crystal misorientation. This is supported by X-ray observations for dislocation density and EBSD (electron backscattering diffraction) for the misorientation.
\end{abstract}

\section{Key words}

Nonlinear acoustics, Plastic strain, EMAT, Acoustoelasticity, EBSD

\section{1 緒言}

多くの機械構造物, 機器は稼働中に塑性ひずみを生じ ることがある．金属材料では，引張強さや延性などの機 械的性質に，転位の運動・増殖が影響を及ぼしている ${ }^{1)}$. 過大な塑性変形（またはひずみ）は，延性を低下させた り, 機器や構造物の破壊を早めたりするため, 化学装置, 運輸機械, 火力や原子力機器の安全基準に塑性変形も含 まれている ${ }^{2)}$. そこで塑性変形の程度を調べることは実際 上重要である.

塑性変形の検出法としては, 腐食法, モアレ法,3), 電子 後方散乱(electron backscattering diffraction; EBSD) ${ }^{4)}, \mathrm{X}$ 線 5), バルクハウゼンノイズ法 ${ }^{6)}$ ，超音波法 ${ }^{7)}$ な゙があるが， 特定の材料, 前処理の必要性, 表面上の大変形の検出に 限定されるなど制限があった。 その中で超音波法は，材 料の制限がなく，従来から多用されている，金属材料が 塑性変形する場合，塑性変形は原子のすべりであるので 巨視的弾性率は変化しないが，材料内部には転位などの 欠陥が累積され，超音波速度の変化として検出できるこ
とがすでに報告されている ${ }^{7)}$. その変化量は数\%以下であ り, 検出感度の高い新検出法が望まれている ${ }^{8)}$.

本研究では，転位など材料微細組織の変化に，従来の 線形超音波特性より敏感である非線形超音波法を塑性変 形の検出に適用しようとした ${ }^{9), 10)}$.ここでは, 非線形超音 波法に電磁超音波共鳴法 (Electromagnetic Acoustic Resonance: EMAR 法) ${ }^{11)}$ を適用した評価方法で, 引張試験 中のひずみ量と非線形超音波量との関係を示すともに, 微細組織との関係を明らかにすることを目的とした。 EMAR 法は, 非接触で超音波を送受信できる電磁超音波 探触子(Electromagnetic Acoustic Transducer: EMAT) ${ }^{11)}$ を 共鳴測定に適用した計測法である。非線形超音波法では, 一般に次のような 5 つの非線形音響特性: (1)高調波の発 生,(2)分調波の発生, (3)共鳴周波数の移動, (4)非線形 3 波 相互作用，(5)音弾性効果の観察から評価をしている 9),12). これまでの非線形超音波法を用いた損傷や変形の評価に 関する研究においては，接触式の圧電超音波センサーを 用いて, (1)高調波の成分（主として 2 次高調波）の振幅の

$\dagger$ 原稿受理 平成 30年 7月 11日 Received July 11, 2018 @2019 The Society of Materials Science, Japan

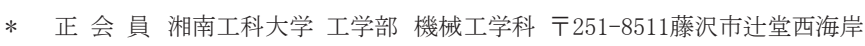

Dept. Mechanical Engineering, Shonan Inst. of Tech., Tsujido-Nishikaigan, Fujisawa 251-8511.

* 湘南工科大学 工学部 機械工学科 テ251-8511藤沢市辻堂西海岸

Dept. Mechanical Engineering, Shonan Inst. of Tech., Tsujido-Nishikaigan, Fujisawa 251-8511.

** 正会員 (株)原子力安全システム研究所 テ919-1205 福井県三方郡美浜町佐田

Institute of Nuclear Safety System, Inc., Sata, Mikata-gun, Fukui 919-1205.

*** 正 会 員 中央発條(株) 广470-0225 みよし市福田町

Chuo Spring Co., Ltd, Fukuda-cho, Miyoshi, 470-0225. 


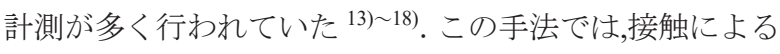
非線形性と計測システムによる非線形性から損傷に伴う 非線形性を抽出する難しさがある。そこで, 本研究では, EMAR 法を用いて機械構造用炭素鋼 S25C の平板の引張 試験中の 3 つの非線形超音波量: (3)非線形超音波スペク トロスコピー(Nonlinear Resonant Ultrasound Spectroscopy: NRUS) ${ }^{19)}$ 法によって求めた振幅依存性による共鳴周波 数の移動, (4)非線形 3 波相互作用による振幅 ${ }^{20)}$, (5)超音波 の伝ぱ方向と応力值で音の伝ぱ速度が変化することを利 用した音弾性効果から評価し，その 3 つの非線形音響特 性の相関関係と引張試験中の微細組織の变化との関係を 明らかにした。また，新たに開発した 1 つの EMAT で非 線形 3 波相互作用による振幅計測の有効性を示した.

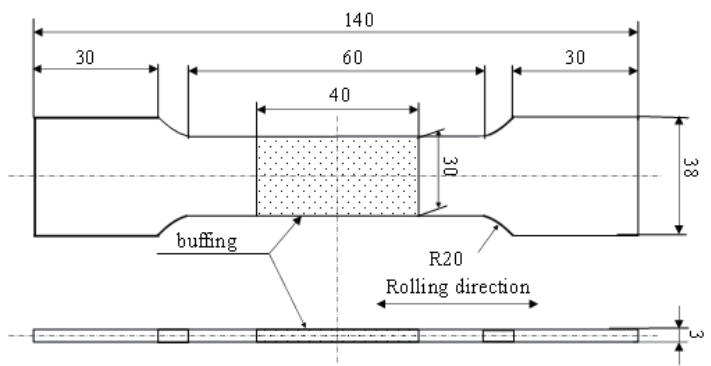

Fig. 1 Geometry of specimen.

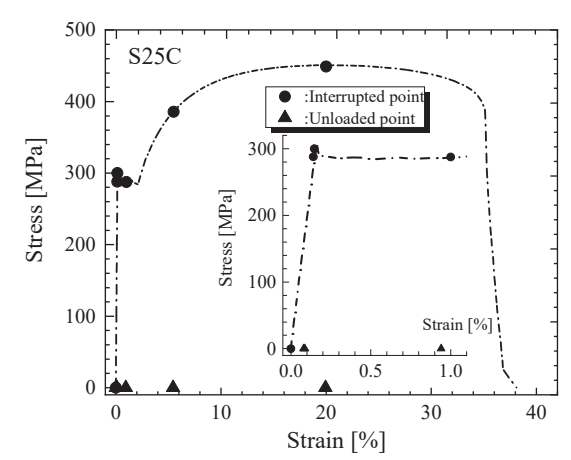

Fig. 2 Interrupted points on stress-strain curve for S25C carbon steel.

\section{1 供試材}

\section{2 供試材および実験方法}

市販の S25C 圧延材を焼なまし $(1,133 \mathrm{~K} \times 1,800 \mathrm{~s}$ 保持 後, 炉冷）したものを供試材として用い，平板の引張試 験片を複数本作製した ${ }^{21)}$. その形状を Fig.1 に示す. 引張 方向は圧延方向と平行である。室温下でまず 1 本の引張 試験片を用いて破断まで引張試験を行い，その後，複数 本の試験片に異なる引張ひずみまで荷重をかけ，除荷し 途中止め引張試験片を複数本作成した. Fig. 2 に途中止め 引張試験の条件を示す. 上降伏点手前, 上降伏点, 下降 伏点, 下降伏点と引張強さの間, 引張強さで途中止めを している. 図中ののが途中止め点, $\boldsymbol{\Delta}$ が除荷時の点である. 超音波計測は除荷後実施した。また除荷後室温にて，X

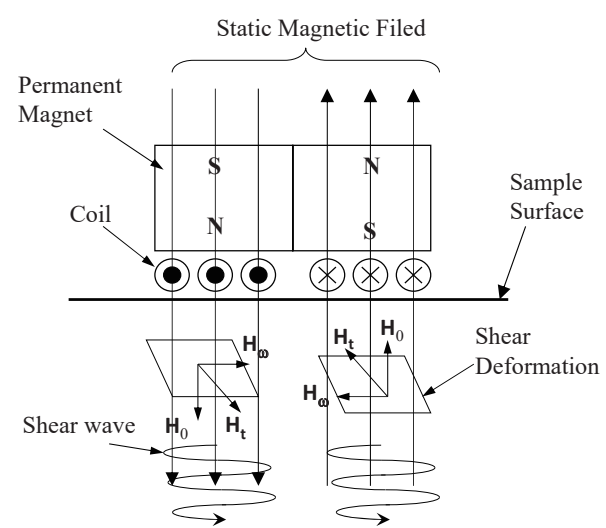

Fig. 2 Generation mechanism of the polarized shear wave by magnetostrictive effect. $\mathbf{H}_{\mathbf{0}}, \mathbf{H}_{\omega}$ and $\mathbf{H}_{\mathbf{t}}$ denote the bias field, the dynamic field and the total field being composed of the vector summation, respectively.

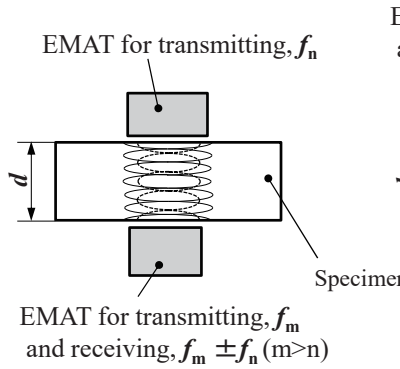

EMAT for transmitting, $f_{\mathrm{n}} f_{\mathrm{n}}$ and receiving, $f_{\mathrm{m}} \pm f_{\mathrm{n}}(\mathrm{m}>\mathrm{n})$

(a)

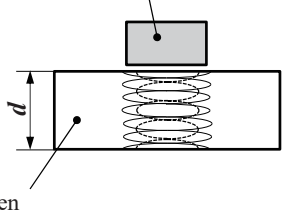

(b)

Fig.3 Experimental arrangements for three wave mixing techniques in (a) previous our study ${ }^{21,22)}$ and (c) present study.

線回析法を用いて転位密度と EBSD 法により方位差解析 を行った.

\section{2 非線形超音波特性の計測方法}

非線形超音波特性の計測には，横波垂直入射型 $\mathrm{EMAT}^{11)}$ を用いた. この EMAT はトラック状に巻いた平面 コイルと一対の永久磁石からなり, 磁わい効果を利用し て, 試料表面に垂直に伝ぱする横波を送受信する ${ }^{11)}$. EMAT の送受信の有効面積は $10 \times 10 \mathrm{~mm}^{2}$ である. 平面コ イルは, 垂直方向に 3 層の積層から構成され, 試料に近 い平面コイルが受信を，その上の 2 層が送信を行うよう になっている.これにより 1 つの EMAT で非線形 3 波相互 作用による非線形超音波特性を計測できるように開発し た. 横波の偏向方向は, 圧延方向と平行と直交の 2 方向 を用いた。

3つの非線形音響特性 : (3)共鳴周波数の振幅依存性の変 化, (4)3 波相互作用による振幅の計測方法, (5)超音波の音 速が応力によって変化する音弾性の各々について以下に 述べる. (3)共鳴周波数の振幅依存性の計測は, NRUS 法に より，比較的低振幅から高振幅まで試料を加振しながら， 試料の相対的な共鳴周波数の移動(共鳴周波数のひずみ振 幅の周波数依存性)を計測することで, 材料内部の微細組 織の変化を調べる. 本研究では, EMAT を駆動する電圧を $10 \%$ から 100\% (156Vp-p 1560 Vp-p)の間で測定し, 共鳴周 
波数シフト $\Delta f$ を振幅に依存しない共鳴周波数 $f_{0}$ (電圧を $10 \%$ での共鳴周波数)で除した $\Delta f f f_{0}$ を NRUS 法における非 線形超音波量として定義する ${ }^{19)}$. (4)非線形 3 波相互作用 の測定においては，過去の研究では試料内に二つの探触 子から異なる周波数を発生させて，この時 2 つの超音波 の相互作用により第 3 の超音波が発生するのを計測し， その第 3 波の振幅を非線形超音波量としていた ${ }^{20)}$. 我々 は 3 波相互作用法に EMAR 法を適用させた計測方法を提 案してきた[Fig.3(a)] 21), 22). その方法は, 2 つの EMAT を厚 さ方向に対向させ，双方から異なる $n, m$ 次 $(m>n)$ の共鳴周 波数 $f_{\mathrm{n}}, f_{\mathrm{m}}$ ( $n$ 次の共鳴周波数は次式で表される $f_{n}=n V / 2 d, V$ : 横波音速, $d$ :板厚）を送信し，一方でその和また差の成分 $f_{\mathrm{m}}-f_{\mathrm{n}}$ の振幅を測定していた. 本研究では, 1 つの EMAT で 3 波相互作用法を可能にした新たな計測方法を提案する [Fig.3(b)]. 3 層積層の平面コイルからなる 1 つの EMAT において, 永久磁石に近い 2 層のコイルから，それぞれ異 なる共鳴周波数 $f_{\mathrm{n}}, f_{\mathrm{m}}$ の超音波を厚さ方向に送信し(それ ぞれの最大振幅 $\left.A_{1}, A_{2}\right)$, 試料の近い 1 層目のコイルで，そ の和また差の成分 $f_{\mathrm{m}} \pm f_{\mathrm{n}}$ の振幅 $\mathrm{A}_{3}$ を測定する[Fig.3(c)]. ここでは, 2 つ送信の共鳴周波数のモード次数 $n, m$ が素 数か, または約数, 倍数とならないモード次数 $n, m$ を選 定し，各モードの倍数の成分(高調波成分)の影響を避けた 22)。ここでは非線形超音波量を $A_{3} /\left(A_{1} A_{2}\right)$ と定義した。 今回 の方法では，1つの EMAT で一方向から計測できるよう になり,実用的になった。

(5)超音波の音速が応力に依存して変化する音弾性効果 について説明する ${ }^{11), 23)}$. 音速は定在波の共鳴周波数 $f_{n}=n V / 2 d$ の関係から，直接，共鳴周波数から評価できる. 今, 1 つの直交異方性の軸から角度 $\theta$ だけ傾いた方向に主 応力が働く平面応力状態を考える(Fig.4). この場合，横波 の偏向方向は集合組織による異方性と応力による異方性

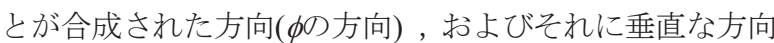
である．２つの主方向に偏向した音速差をその平均音速 で除した量を音響異方性 $B$ と呼んでいる，音弾性法則に よると音響異方性と主応力差には式(1)の関係がある.

$$
B=\sqrt{B_{0}^{2}+2 B_{0} C_{A}\left(\sigma_{1}-\sigma_{2}\right) \cos 2 \theta+C_{A}\left(\sigma_{1}-\sigma_{2}\right)^{2}}
$$

ここでは $\sigma_{1}, \sigma_{2}$ は主応力, $B_{0}$ は組織異方性， $C_{A}$ は複屈折 音弾性定数である.また偏向方向 $\phi$ は式(2)で示される.

$$
\tan 2 \phi=\left(C_{A}\left(\sigma_{1}-\sigma_{2}\right) \sin 2 \theta\right) /\left(B_{0}+C_{A}\left(\sigma_{1}-\sigma_{2}\right) \cos 2 \theta\right)
$$

特に, 主応力と直交異方性の軸が一致する場合 $(\theta=0)$, 式(1)は式(3)のようになり, 2 方向に偏向した横波と主応力 差は線形関係になる，音響異方性 $B$ は，Fig.5 より主応力 $\sigma_{1}, \sigma_{2}$ 方向に，それぞれ平行な偏向方向をもつ共鳴周波数 $f_{\mathrm{n}}^{(1)}, f_{\mathrm{n}}^{(2)}$ を用いて表すと， $B$ は式(3)で表される。この音響 異方性 $B$ を非線形超音波量とした。

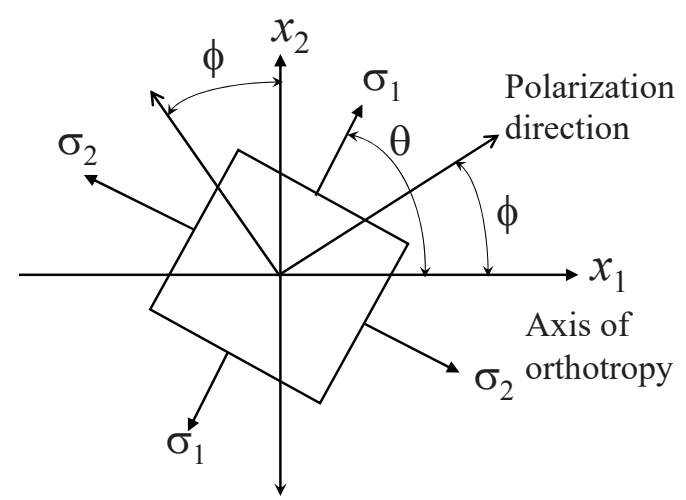

Fig.4 Two-dimensional coordinate system aligned the axes of orthotropic-texture anisotropy with the principal stress and the shear-wave polarization. ${ }^{11)}$

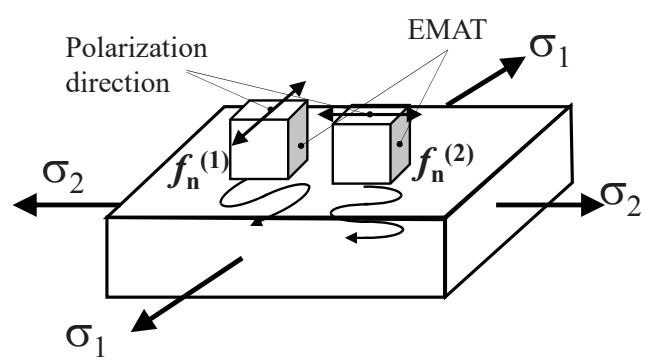

Fig.5 Polarized shear-waves to measure acoustic birefringence in the plane stress condition.

$B=B_{0}+C_{A}\left(\sigma_{1}-\sigma_{2}\right)=\frac{f_{n}^{(1)}-f_{n}^{(2)}}{\left(f_{n}^{(1)}+f_{n}^{(2)}\right) / 2}$

計測にはスーパーヘテロダイン位相検出器を搭載した RITEC RAM5000-SNAP を使用した。非線形超音波量の計 測と併せて,減衰係数（単位時間当たりの減衰）も計測し た. 計測方法は参考文献 ${ }^{11}$ 参照.

\section{3 組織観察}

組織観察では，X 線による転位密度と EBSD 法による 方位差解析を行った。転位密度の計測には，X 線回析装 置を用いた。試験条件は，ターゲットは $\mathrm{Cr}$ ，電圧 $40 \mathrm{k} \mathrm{V}$, 電流 $30 \mathrm{~mA}$ ，測定回折面，回折角は (211) で $156.41^{\circ}$ ，コ リメータ径 $\phi 1 \mathrm{~mm}$ ，照射時間 $30 \mathrm{~s}$ である。転位密度の算出 には，フォークト関数を用いて，単一の回折プロファ イルより粒径とひずみを分離する手法を用いた ${ }^{21)}$

EBSD 法による方位差解析では， Fig.1 の引張試験片 の中央部から長手方向に平行な断面を切り出し観察した. 観察断面は, 樹脂埋め後, 表面を最終 $1 \mu \mathrm{m}$ のダイヤモン ドペーストで仕上げた後，コロイダルシリカ（OP-U）に よる仕上げ研磨を行った。電界放射型走査型電子顕微鏡 （Carl Zeiss ULTRA55）に備え付けられた EBSD 測定シス テム（OIM Data Collection ver. 5.2）を用いて，試料表面の 結晶方位分布を測定した。回折パターンを取得するため に CCD カメラの画素数は $1392 \times 1040$ ピクセルとし，ス テップサイズは， $0.5 \mu \mathrm{m}$ で， 1 回あたり $150 \times 150 \mu \mathrm{m}^{2}$ の 測定範囲（301×301 個の測定点）に対し方位測定を行っ た．測定は 1 サンプルに 2 回ずつ実施した。 


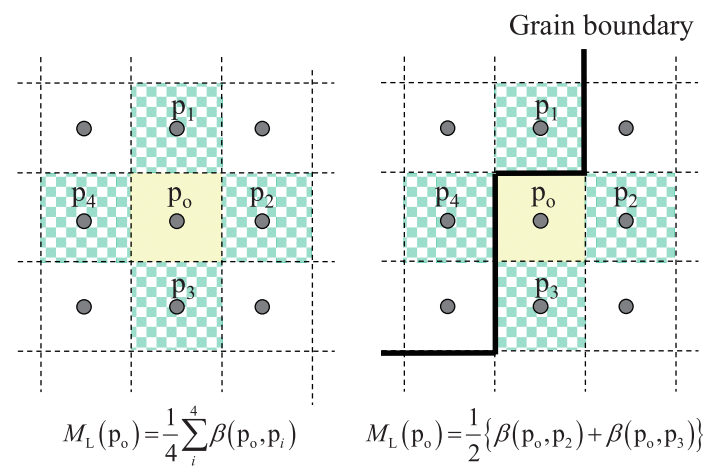

Fig. 6 Definition of local misorientation.

釜谷らの開発した結晶方位差解析用ソフトウェア MADAM (Misorientation Analyzer for DAmage Measurement) 24),25)を用いて局所方位差, $M_{\mathrm{L}}$ を次式より求めた.

$$
M_{L}\left(p_{0}\right)=(1 / 4) \sum_{i=1}^{4} \beta\left(p_{0}, p_{i}\right)
$$

ここで, $\beta(i, k)$ は, 点 $i$ と $k$ の方位差を表す. 点 $\mathrm{p}_{\mathrm{i}}$ は Fig.6 に示すように, 点 $\mathrm{p}_{0}$ を中心に隣接する 4 つの測定点を示 す．ただし，点 $\mathrm{p}_{0}$ と点 $\mathrm{p}_{\mathrm{i}}$ の間に結晶粒界が存在する場合 は計算から除外した。方位差がしきい值となる角度（こ こでは $5^{\circ}$ とした）以上となる測定点の境界が，閉じた領 域を形成した場合に，その境界を結晶粒界と定義した。1 回の測定において得られる結晶方位は 90,601 点であるが, それぞれの点で算出される局所方位差 $M_{\mathrm{L}}$ の度数分布は 対数正規分布で近似できる ${ }^{26)}$. そこで，この分布の対数 平均を局所方位差平均 $M_{\mathrm{ave}}$ として次式により算出した ${ }^{27)}$.

$$
M_{\text {ave }}=\exp \left[\frac{1}{n} \sum_{i=1}^{n} \ln \left\{M_{\mathrm{L}}\left(\mathrm{p}_{i}\right)\right\}\right]
$$

ここで, $n$ はデータ数を示す. 方位測定の位置によって は，転位や析出物などの影響で回折パターンが不鮮明に なり結晶方位の同定が困難であったり，結晶粒界近傍で は, 2 つ上の結晶方位の回折パターンが重なり結晶方位 が正しく同定されなかったりする場合もある。このよう な点では周囲の測定点の方位差が大きくなり, 独立した 結晶粒として認識される，そこで，9個以下の測定点で構 成される結晶粒は，正しく測定ができなかった測定点（以 後，ブランク点と呼ぶ）として， $M_{\mathrm{ave}}$ などの解析には用い なかった. $n$ はブランク点を除いた測定点数となる.また, 結晶方位の変化を表す指標として, 次式で定義される $M C D$ (Modified Crystal Deformation) 值も用いた ${ }^{25)}$.

$$
M C D=\exp \left[\frac{\sum_{k=1}^{n_{\mathrm{g}}}\left\{\sum_{i=1}^{n_{k}} \ln \left\{\beta\left(m_{k}, p_{i}\right)\right\}\right\}}{\sum_{k=1}^{n_{\mathrm{g}}} n_{k}}\right]
$$

ここで, $m_{\mathrm{k}}$ は結晶粒 $k$ に含まれる測定点の平均方位を示 し, $n_{\mathrm{k}}$ は結晶粒 $k$ に含まれる測定点の数, $n_{\mathrm{g}}$ は結晶粒数を 示す. $\beta\left(m_{k}, p_{i}\right)$ は結晶粒の平均方位と, その結晶粒内測 定点との方位差を示すことから， $M C D$ は個々の測定点で はなく, 結晶粒全体の変形量を反映したパラメータとな っている（市販の EBSD 装置で算出される粒内方位差 GROD: Grain Reference Orientation Deviation パラメータの 対数平均に相当する). また, 方位差には $0.1 \sim 1^{\circ}$ 程度の 誤差が含まれることから, 詳細な方位差分布を得るには 誤差の影響を低減させる必要がある，そこで平滑化フィ ルター28)を用いた。

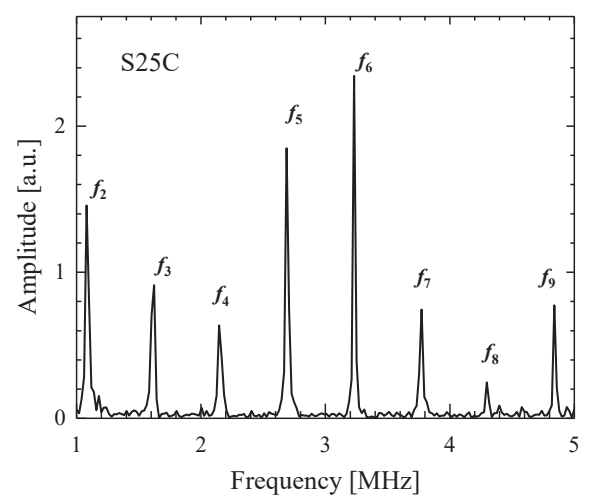

Fig.7 Measured resonant spectrum for S25C tensile specimen.

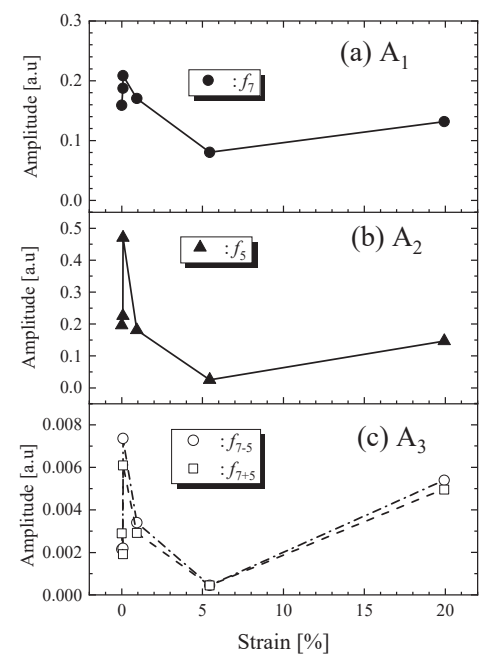

Fig.8 Evolutions of (a) (b) fundamental wave amplitudes, $A_{1}, A_{2}$ at $f_{7}$ and $f_{5}$ and (b) interaction wave amplitudes, $A_{3} \mathrm{~s}$ at $f_{12}$ and $f_{2}$ during tensile test in $\mathrm{S} 25 \mathrm{C}$.

\section{3 実験結果および考察}

\section{1 非線形超音波特性}

Fig. 7 に S25C材の初期材の共鳴スペクトルを示す. 本 研究では, 5 次モード $f_{5}(2.7 \mathrm{MHz}$ 近傍 $)$ と 7 次モード $f_{7}$ (3.8MHz近傍)を用いて, NRUSによる $\Delta f f f_{0}$ (3), 3 波相互 作用法による非線形超音波量(4), 音響異方性 $\mathrm{B}$ (5))並び に線形超音波特性; 減衰係数 $\alpha$, 相対音速 $\Delta V / V_{0}\left(\Delta V=V-V_{0}\right.$, 
$V$ :音速， $V_{0}$ : 初期音速) の測定を行った. 3 波相互作用法は， $f_{7}$ と $f_{5}$ の共鳴周波数を用いて相互作用させ, 和と差のモー ド次数 $\left(f_{12}=f_{7}+f_{5}, f_{2}=f_{7}-f_{5}\right)$ を測定し，その時の振幅を用いて， $\mathrm{A}_{3} /\left(\mathrm{A}_{1} \mathrm{~A}_{2}\right)$ の非線形超音波量を求めた $\left(\mathrm{A}_{1}: f_{7}\right.$ の最大振幅, $\mathrm{A}_{2}$ : $f_{5}$ の最大振幅, $\mathrm{A}_{3}$ : 相互作用で発生した波 $f_{12}$ または $f_{2}$ の最大振幅). 音響異方性 $\mathrm{B}$ は, 7 次モード $f_{7}$ における横波 の偏向方向が引張方向に平行な $f_{7}^{(1)}$, 直交する $f_{7}^{(2)}$ の共鳴 周波数から求めた。

Fig. 8 に引張試験中の $f_{7}$ と $f_{5}$ の基本波の振幅 $\left(\mathrm{A}_{1}, \mathrm{~A}_{2}\right)$ 変 化 (Figs.8(a)，(b)) と 3 波相互作用法における和と差のモ 一ド次数 $\left(f_{7+5} f_{7-5}\right)$ における $2 つ$ 非線形超音波量 $\mathrm{A}_{3}$ の変 化を示す[Fig.8(c)]． 横軸は引張試験を除荷時のひずみ(塑 性ひずみ)である。横波の偏向方向は荷重方向と平行であ る. $A_{1}, A_{2}$ と $2 つ の A_{3}$ は，初期から上降伏点まで増加し， その後減少し,引張強さ近傍で僅かに増加している。 $A_{3}$ は $A_{1}, A_{2}$ の 100 分の 1 近い值であった.

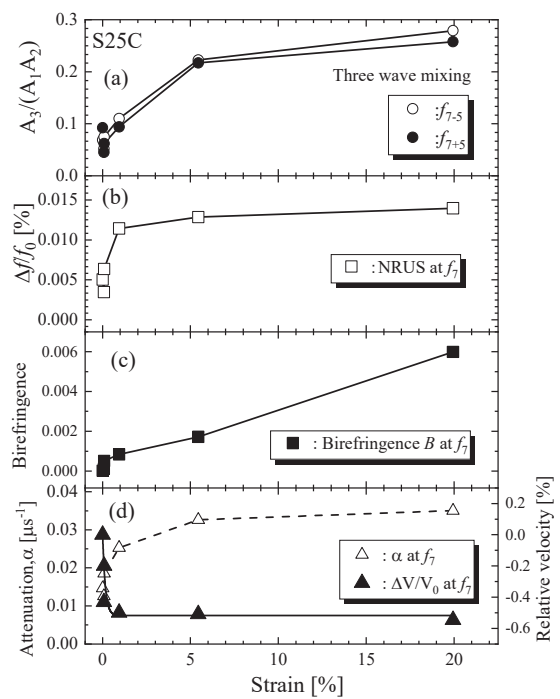

Fig. 9 Evolutions of (a) the nonlinearity with three wave mixing, (b) the nonlinearity with NRUS, (c) birefringence and (d) attenuation coefficient and relative velocity for S25C carbon steel during tensile test.

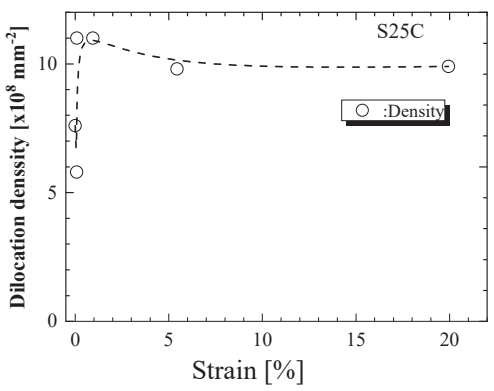

Fig.10 Change of dislocation density for S25C carbon steel during tensile test.

Fig.9 に引張試験中の 3 波相互作用法による非線形超音 波量 $A_{3} /\left(A_{1} A_{2}\right)$, NRUS による $\Delta f l f_{0}$, 音響異方性 $B$ と超音波 減衰と相対音速比の変化を示す. $A_{3} /\left(A_{1} A_{2}\right)$ は，ひずみの上 昇につれて, 増加した. $\Delta f f f_{0}$ および $\alpha$ も同様な傾向を示し
た。 その増加量は, $A_{3} /\left(A_{1} A_{2}\right)$ はより 小さい，音響異方性 $B$ は, 上降伏点まで微増し, その後ひずみに比例して増加 した. $\Delta V / V_{0}$ は, 下降伏点まで急激に減少後, その後緩や かに減少する傾向を示したが，変化量は最大でも $0.5 \%$ 程 度の小さなものであった。

\section{2 組織観察}

引張試験中の $\mathrm{X}$ 線回折測定により得た転位密度の変化 を Fig.10 に示寸．計測場所は試験片中央部である。初期 から上降伏点手前から急激に上昇し，下降伏点から僅か に減少していった。

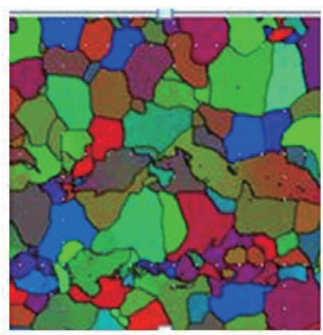

(a)

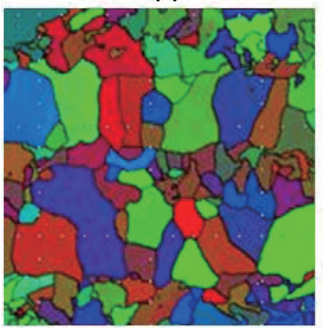

(c)

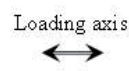

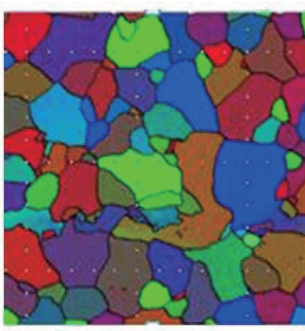

(b)

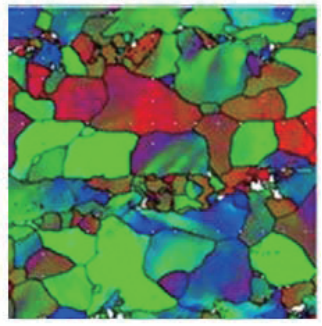

(d)

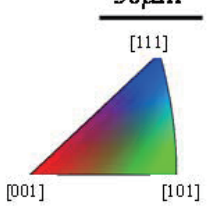

Fig.11 Inverse pole figure maps for S25C carbon steel during tensile tests [(a) before tensile test, (b) at upper yield stress, (c) at lower yield stress, and (d) at tensile strength].

Fig.11に EBSD 法を用いた引張試験中の結晶方位マッ プ(IPF map : Inverse pole figure map) を示す. Fig.11(a) は, 初期材(ひずみ $\varepsilon=0 \%)$, Fig.11(b)が上降伏点 $(\varepsilon=0.16 \%)$, Fig.11(c)が下降伏点 $(\varepsilon=1.0 \%)$, そして Fig.11(d)が引張強さ $(\varepsilon=20 \%)$ でのマップある. 引張方向は図の左右方向である. 塑性ひずみにより結晶内のカラーコントラストが変化し ているのがわかる。

Fig.12 に局所方位差 $\left(\mathrm{M}_{\mathrm{L}}\right)$ の分布を示寸. 前述と同様 に. Fig.12(a)は, 初期材(ひずみ $\varepsilon=0 \%)$, Fig.12(b)が上降伏 点 $(\varepsilon=0.08 \%), \quad$ Fig.12(c) が下降伏点 $(\varepsilon=0.9 \%)$, そして Fig.12(d)が引張強さ $(\varepsilon=20 \%)$ でのマップある. 図中には結 晶粒界と判断された境界を実線で示した。 $M_{\mathrm{L}}$ は, 横しま 上に比較的大きな帯状の分布が見られた。この横しまは 圧延方向と一致していた，そのしまの $M_{\mathrm{L}}$ が塑性ひずみの 増加につれて濃くなっていった. 引張強さに[Fig.12(d)]お 
いて，正しく測定ができなかったブランク点が， $M_{\mathrm{L}}$ が高 い領域(しま状)近傍で多く見られる(図中の矢印近傍).

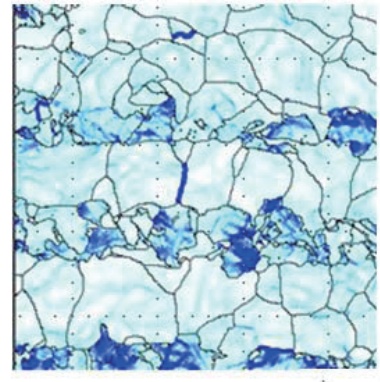

(a)

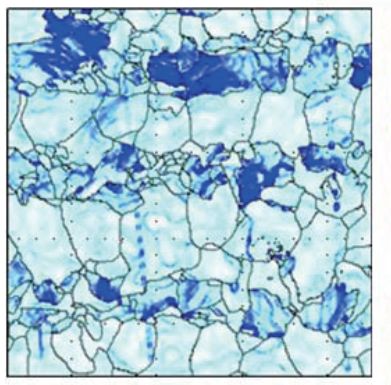

(c)

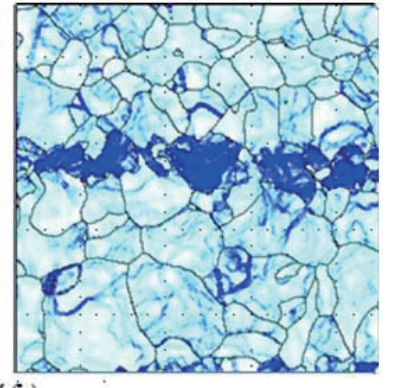

(b)

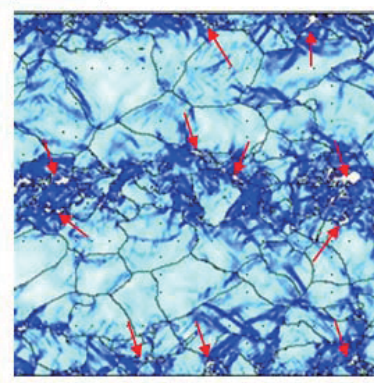

(d) $50 \mu \mathrm{m}$
Fig.12 Mapping data of local misorientation $\left(M_{\mathrm{L}}\right)$ during tensile test in S25C [(a) before tensile test, (b) at upper yield stress, (c) at lower yield stress, and (d) at tensile strength].

Fig.13, 14 にひずみ量と局所方位差平均 $M_{\mathrm{ave}}$ の関係，ひ ずみ量と局所方位差平均 $M C D$ の関係を示す. $M_{\mathrm{ave}}$ はひず み量とともに大きくなる傾向にあるが単調増加ではなか った. $M C D$ も $M_{\text {ave }}$ と同様にひずみ量が大きくなるにつれ て増加した. Fig.12より EBSD 解析領域に含まれるしま状 部分の本数により $M_{\text {ave }}$ や $M C D$ の值は影響を受けるよう に思われる. 今回の計測では帯状の本数の異なる 2 点で 計測を実施した結果を Fig.13, 14 に示している. 2 点の差 異は小さく, 特に $M C D$ の方がより小さい. この結果より この解析手法は妥当だと考える.

このしま状の領域は(Fig.12), 圧延時不純物の偏析帯が伸 ばされ，オーステナイト $(\gamma \mathrm{Fe})$ 領域からの冷却過程で，ま ず偏析帯にフェライト $(\alpha \mathrm{Fe})$ が形成され, 炭素はこの偏析 帯から排除され，そして，その偏析帯にフェライトが帯 状になったフェライト帯が形成され，それが本供試材の しま状の部分で，その他の部分がパーライト帯と考えら れる ${ }^{29)}$. 引張応力により柔らかいフェタイト帯が優先的 に変形し, GN 転位 ${ }^{30}$ ) (各結晶内部の変形に対応した幾何 学的に必要な転位 geometrically necessary dislocations: GN 転位) が増加し，その部分の結晶粒の局所的な方位差 $M_{\mathrm{L}}$ が増加し $M C D$ が増加したと考えられる。それゆえ, $M C D$ は塑性ひずみ量とよい相関を示している，さらに，測定 間隔や測定条件の影響も受けにくいという特徴を有して いるので，塑性ひずみ量を測定する尺度となり得ると考 えられる。

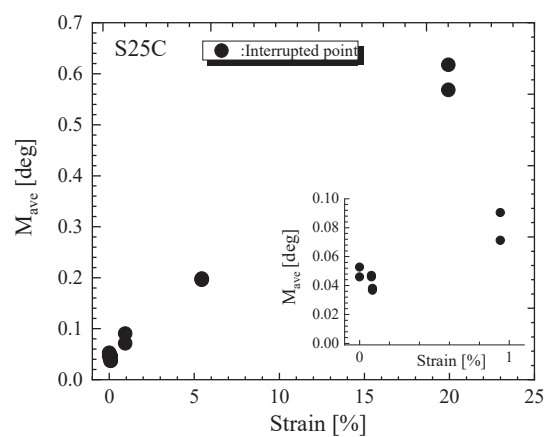

Fig.13 Change of local misorientation average $\left(M_{\text {ave }}\right)$ during tensile test in S25C.

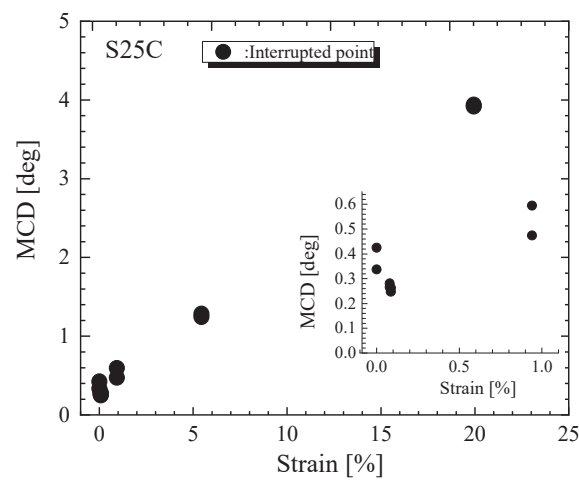

Fig.14 Change of Modified Crystal Deformation $(M C D)$ during tensile test in $\mathrm{S} 25 \mathrm{C}$.

固体が示寸非線形音響現象の原因はさまざまであるが, 下記のような 3 つの要因が知られている ${ }^{31)-35) . ~}$

a) 固体を構成する結晶格子が有する非対称性 ${ }^{31,33)}$

b) 転位の運動の非線形性 ${ }^{34)}$

c）固体に内在する欠陥やき裂により生じる非線形性 ${ }^{35)}$ 今回は, き裂が観察されていないことから, 組織変化に ともなう要因の a), b)が要因になる.

2 つの非線形超音波量 [Fig.9(a), (b)]は, 減衰係数の変化 と同じ傾向を示している.これまでの我々の研究では, 疲労やクリープ損傷中の減衰係数の変化は, 転位組織の

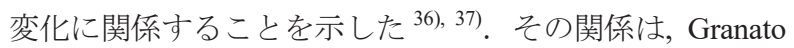

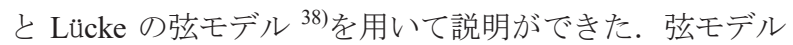
では, 転位の振動を,粘弾性体中の弦の振動としてモデル 化し, 減衰係数 $\alpha$, 相対音速 $\Delta V / V_{0}$ と転位密度 $\Lambda$, 平均転位長 さ $L$ との関係を以下のように導いた.

$$
\begin{aligned}
& \alpha=C_{1} \Lambda L^{4} f^{2} \\
& \Delta V / V_{0}=-C_{2} \Lambda L^{2}
\end{aligned}
$$

ここで, $C_{1}, C_{2}$ は正の定数であり, 剛性率, 転位運動の比 粘性係数, 転位の有効線張力, バーガースベクトルに依 存する.このモデルによると, 減衰係数は転位密度 $\Lambda$, 転 位の平均長さ $L$ の 4 乗と振動数 $f$ の 2 乗に比例する. 音 
速は $\Lambda$ と $L$ の 2 乗に比例して減少する。 また超音波減衰 は超音波により生じる応力とひずみのヒステリシスに起 因し,その不可逆的な動的過程は,転位運動により引き起 こされる.そしてヒステリシスループの面積が超音波 1 サイクル中に吸収されるエネルギーである。これが超音 波減衰として観察される。この非線形なヒステリシスは, 超音波により引き起こされるひずみ振幅 $\Delta \varepsilon$ に比例する(た だし，大きなひずみ振幅において). そして共鳴周波数の 移動量 $\Delta f$ は, $\Delta \varepsilon$ に比例する ${ }^{19)}$.

$$
\Delta f / f_{0} \propto C_{3} \Delta \varepsilon
$$

ここで $C_{3}$ は，非線形ヒステリシスパラメータである ${ }^{19)}$. これらの関係は, すべての転位を対象としているわけで はなく，超音波のような低応力波に対しても振動できる 可動転位だけを対象にしていることである.したがって, 結晶粒界やサブグレインに拘束されている転位は，超音 波特性に貢献できない. Fig.10 の X 線回折により得られ る転位密度は, 前述の可動転位と拘束された転位を合わ

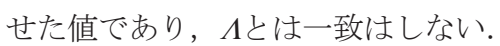

引張試験中の組織と超音波量の関係を考えると, Fig.10 の $\mathrm{X}$ 線による転位密度では, 初期から上降伏点手前から 急激に上昇している。 その間, 非線形超音波量, 減衰係 数も急増していることから，この領域までは転位の増殖 が超音波量を支配していると考える. それ以降の領域で は，転位組織だけでなく，Fig.12における帯状組織 (集合 組織)でのひずみ（引張方向）が増加し[Fig.14:MCD の増 加から推定], 材料の異方性が増加[Fig.9(c)：B の急増]し 39), 幾何学的や材料非線形性 ${ }^{30)}$ が増加したと考えられる. また，今回の計測法では，1 個の EMAT で3波相互作用法 が用いられる計測方法を開発し有用な結果を得ることが できた。 EMAR 法を用いた非線形超音波法は，広範囲で 塑性ひずみ量と良い相関関係があることから[Fig.9], 塑性 ひずみ測定する尺度となり得る可能性を示している.

\section{4 結 言}

非接触・超音波電磁探触子 EMAT を用いて，低炭素鋼 $\mathrm{S} 25 \mathrm{C}$ の引張試験中の塑性ひずみに誘起された非線形超音 波量と微細組織の変化との関係を調べた.

1) 共鳴周波数の移動, 3 波相互作用法と音弾性効果によ る音響異方性による 3 つの非線形超音波量と減衰係 数は, 塑性ひずみと良い相関関係があった。 それら は，転位密度や結晶方位差に起因し，X 線による転 位密度計測や EBSD 法よる観察の結果から裹付けら れる。

2) 開発した 3 層構造の平面コイルをもつ EMAT は， 1 つの EMAT で 3 波相互作用法による非線形超音波量 を高精度に計測できることを可能にした。

3）EMAR 法を用いた非線形超音波法は，塑性ひずみ測 定する尺度となり得る可能性を示している。

\section{参 考 文 献}

1) E. C. Aifantis, "The Physics of plastics deformations", International Journal of Plasticity, Vol. 3, pp.211-247 (1987).

2) Y.F. Shen, X.X. Li, X. Sun, Y.D. Wang and L. Zuo, "Twinning and martensite in a 304 austenitic stainless steel", Materials Science \& Engineering A, Vol 552, pp.514-522 (2012).

3) Y. Morimoto, M. Fujigaki and A. Masaya, "Displacement and strain distribution measurement by sampling Moire method", Journal of Vacuum Society of Japan, Vol.54, No.1, pp.32-38 (2014).

4) M. Kamaya, A. J. Wilkinson and J. M. Titchmarsh, "Quantification of plastic strain of stainless steel and nickel alloy by electron backscatter diffraction", Acta Materialia, Vol. 54, pp.539-548 (2006).

5) T. Shintani and Y. Murata, "Evaluation of the dislocation density and dislocation character in cold rolled Type 304 steel determined by profile analysis of X-ray diffraction", Acta Materialia, Vol.59, pp. 4314-4322 (2011).

6) A. Vincent, L. Pasco, M. Morin, X. Kleber and M. Delnondedieu, "Magnetic Barkhausen noise from strain-induced martensite during low cycle fatigue of 304L austenitic stainless steel", Acta Materialia, Vol. 53, pp.4579-4591 (2005).

7) Y. Tanaka, C. Masuda, C. Miyasaka and F. Uchino, "Effect of several factors evaluation of damage for metal matrix composites by scanning acoustic microscope", Journal of Society Materials Science Japan, Vol.41, No.466, pp. 1061-1067 (1992).

8) A. Todoroki, H. Kobayashi, Y. Arai and T. Kobayashi, "A study of image detection of plastic deformation area with acoustic method", Transactions of the JSME A, Vol.60, No.570, pp.494-500 (1994).

9) K. Y. Jhang, "Nonlinear ultrasonic technique for nondestructive assessment of micro damage in material: a review", International Journal of Precision Engineering and Manufacturing, Vol.11, No.1, pp.123-135 (2009).

10) K. Y. Jhang, "Application of nonlinear ultrasonics to the NDE of material degradation", IEEE Transaction on Ultrasonics, Ferroelectrics and Frequency Control, Vol. 47, No.3, pp.540-548 (2000).

11) M. Hirao and H. Ogi, "EMATs for science and industry: nondestructive ultrasonic measurements", pp.1-92, pp.135-196 and pp. 215-226 (2003) Kluwar Academic Publishers, Boston.

12) R.W. Benson and V.J. Raelson, "Acoustoelasticity", Vol.30, Product Engineering, pp.56-59 (1959).

13) A. Hikata, B. B. Chick and C. Elbaum, "Dislocation contribution to the second harmonic generation of ultrasonic waves", Journal of Applied Physics, Vol. 36, pp.229-236 (1965).

14) J.H. Cantrell and W. T. Yost, "Acoustic harmonic generation from fatigue-induced dislocation 
dipoles", Philosophical Magazine A, Vol.69, pp.315-326 (1994).

15) M. Kobayashi, "Ultrasonic nondestructive evaluation of microstructural changes of solid materials under plastic deformation-Part II. Experiment and simulation", International Journal of Plasticity, Vol. 14, pp. 523-535 (1998).

16) M. Kobayashi, S. Tang, S. Miura, K. Iwabuchi, S. Oomori and H. Fujiki, "Ultrasonic nondestructive material evaluation method and study on texture and cross slip effects under simple and pure shear states", International Journal of Plasticity, Vol. 19, pp. 771-804 (2003).

17) S. Baby, B. Nagaraja Kowmudi, C. M. Omprakash, D. V. V. Satyanarayana, K. Balasubramaniam and V. Kumar, "Creep damage assessment in titanium alloy using a nonlinear ultrasonic technique", Scripta Materialia, Vol. 59, pp.818-821 (2008).

18) J. Zhang, S. Li, Fu-Zhen Xuan and F. Yang, "Effect of plastic deformation on nonlinear ultrasonic response of austenitic stainless steel", Materials Science and Engineering A, Vol. 622, pp. 146-152 (2015).

19) K. E-A. Van Den Abeele and J. Carmeliet, "Nonlinear elastic wave spectroscopy (NEWS) techniques to discern material damage, Part II: single-mode nonlinear resonance acoustic spectroscopy" Research Nondestructive Evaluation, Vol.12, No.1 pp.31-42 (2000).

20) G. L. Jones and D. R. Kobett, "Interaction of elastic waves in an isotropic solid", The Journal of the Acoustical Society of America, Vol. 35, No.1, pp.5-10 (1963).

21) T. Ohtani, A. Ishikawa, Y. Ishii and T. Sakakibara, "The variation of tensile plastic strain induced nonlinear acoustic characteristics in low carbon steel", Transaction of Japan society of Spring Engineers, Vol.27, pp.15-18 (2007).

22) T. Ohtani, T. Honma, Y. Ishii, M. Tabuchi, H. Hongo and M. Hirao, "Evolutions of nonlinear acoustics and microstructural change during creep in Gr. 122 steel welded joint", Journal of Society of Materials Science, Japan, Vol. 64, No.2, pp.80-87 (2015).

23) H. Ogi, M. Hirao and H. Fukuoka, "Electromagnetic acoustic resonance to measure stress in thin metal plates", Transactions of the JSME A, Vol.60, No.569 pp.250-257 (1994).

24) M. Kamaya, A. J. Wilkinson and J. M. Titchmarsh, "Measurement of plastic strain of polycrystalline material by electron backscatter diffraction", Nuclear Engineering and Design, Vol. 235, pp.713-725 (2005).

25) M. Kamaya, A. J. Wilkinson and J. M. Titchmarsh, "Quantification of plastic strain of stainless steel and Nickel alloy by electron backscatter diffraction", Acta Materialia, Vol. 54, pp.539-548 (2006)

26) M. Kamaya, "Measurement of local plastic strain distribution of stainless steel by electron backscatter diffraction", Material Characterization, Vol. 60, pp. 125-132 (2009).

27) L. N. Brewer, D. P. Field and C. C. Merriman, "Mapping and assessing plastic deformation using EBSD", In: Electron Backscatter Diffraction in Materials Science Second Edition, edited by A. J. Schwarts, M. Kumar, B. L. Adams, B. L. and D. P. Field, pp. 251-262 (2009), Springer.

28) M. Kamaya, "A smoothing filter for misorientation mapping obtained by EBSD", Materials Transactions, Vol. 51, pp.1516-1520 (2010).

29) H. Sudo, I. Tamura and Y. Nishizawa, "Kinzoku soshiki gaku”, Maruzen, pp.217-219 (2004).

30) F. Delaire, J.L. Raphanel and C. Rey, "Plastic heterogeneities of a copper multicrystal deformed in uniaxial tension: experimental studyand finite element simulations", Acta Materialia, Vol. 48, pp.1075-1087 (2000)

31) D. C. Wallace, "Thermodynamics of crystals", Dover Publisher, pp.14-18 (1972).

32) H. Hirao, "Nonlinear interaction of elastic waves and stress effect", Journal of the Japanese Society for Non-Destructive Inspection, Vol.56, No.6, pp.292-296 (2007).

33) K. Y. Kim, "Thermodynamics at finite deformation of an anisotropic elastic solid", Physical Review B, 54, pp.6245-6254 (1996).

34) R. A. Guyer, K. R. McCall and G. N. Boitnott, "Hysteresis, discrete memory and nonlinear wave propagation in rock: a new paragigm", Physical Review Letter, 74, pp.3491-3494 (1995).

35) O. Buck, W. L. Morris and J. M. Richardson, "Acoustic harmonic generation at unbounded interfaces and fatigue cracks", Applied Physics Letter, Vol. 33 (5), pp.371-373 (1978).

36) T. Ohtani, N. Nishiyama, S. Yoshikawa, H. Ogi and M. Hirao, "Ultrasonic attenuation and microstructural evolution throughout tension-compression fatigue of a low carbon steel", Materials Science and Engineering A, Vol. 442, pp. 466-470 (2006).

37) T. Ohtani, H. Ogi and M. Hirao, "Change of ultrasonic attenuation and microstructure evolution in crept $2.25 \%-1 \%$ Mo Steels", Journal of Society of Materials Science, Japan, Vol.51, pp.195-201 (2002).

38) A. Granato and K. Lücke, "Theory of mechanical damping due to dislocation", Journal of Applied Physics, Vol.27, pp.583-593 (1956).

39) Y. H. Pao, W. Sachse and H. Fukuoka, "Acoustoelasticity and ultrasonic measurement of residual stresses", In: Physical Acoustics, Vol. XVII, eds., W. P. Manson and R. N. Thurston, pp.61-143, Academic Press (1984). 